\title{
Higher Education Curriculum Transformation in and of Radical Immanence: Towards a Free and Creative Ethics
}

\author{
Anné Verhoef \\ ORCID iD: https://orcid.org/0000-0002-9627-1969 \\ Petro du Preez \\ ORCID iD: https://orcid.org/0000-0002-9100-6461
}

\begin{abstract}
The purpose of higher education curriculum transformation has often been justified amidst calls for decolonisation, the redressing of social injustices, preparing students for the world of work, and so on. Noble as this might sound, these justifications lead to an instrumentalist view of higher education curriculum transformation that reinforces a reductionist approach to transformation that is fundamentally transcendentally motivated. A transcendental motivation tends to overlook education as meaningful in and of itself. The problem with such transcendental accounts, goals, or justifications of education is that they deny the immanent meaningfulness that education already has. Gilles Deleuze, with his philosophical concept of the plane of immanence, represents one of the most radical positions on this notion. We examine the implications of Deleuze's radical immanence on discourses of higher education curriculum transformation. We argue that this transformation needs to be complemented by other, more open notions of immanence to open up avenues for a new kind of ethics. First, we offer an analysis of Deleuze's radical immanence. After this, our focus shifts to what higher education curriculum transformation in relation to this plane of immanence entails. Then, we argue that transformation discourses, based on or within such a radical immanence have some significant benefits that should be considered seriously. However, there are also aspects that are not philosophically and educationally
\end{abstract}


tenable. This does not mean that Deleuze's radical immanence should be rejected, but, rather, that the pedagogical value of it should be exploited in combination with other philosophies of immanence, like those of Jean-Luc Nancy and Slavoj Žižek.

Keywords: curriculum transformation, Deleuze, ethics, higher education, radical immanence

\section{Introduction}

The 21 st century poses unprecedented challenges and opportunities for higher education curriculum transformation (Howard 2018; Lourie 2020). Its opportunities are far-reaching and its challenges perhaps even more so. Engaging in any form of research pertaining to education in the 21 st century necessitates a critical engagement with higher education curriculum transformation as a complex matter that is influenced by social, economic, and political agendas ${ }^{1}$. It is often loosely defined and this does not necessarily denote a crisis; it offers opportunities to rethink and research the subject (Du Preez et al. 2016). Such rethinking and researching curriculum transformation is especially important in the $21^{\text {st }}$ century where what constitutes the purpose and nature of higher education is fundamentally disrupted. Such disruption is pivotal to the process of redefining the limits and possibilities of curriculum transformation insofar as it provides a space in which one can engage critically with the transcendental (and, to a lesser extent, the immanent) justifications of higher education. One example of such disruption was the decolonial turn that resulted from the 2015/2016 nation-wide student protests in South Africa during which urgent pleas were made to higher education institutions (HEIs) to radically transform their curricula. (For a more detailed account of this debate, see Du Preez 2018; Du Preez et al. 2020; Le Grange 2016 2017). One might ask to what extent, if any, have these interruptions challenged the hegemonic views about the nature

1 Apart from the social, economic, and political agendas that influence curriculum transformation, there are also historical moments that have had contextual influences on transformation. One example concerns the instrumentalist orientation of education that was augmented by Enlightenment philosophies. Another example is how the positivist, colonialist agenda informed apartheid's interpretations of education. 
and purpose of higher education. The COVID-19 pandemic presents a second challenge to HEIs that, under emergency circumstances, have had to transform their daily workings despite severe socio-economic divides in the country (Du Preez \& Le Grange 2020). HEIs have to grapple with these realities but there has always been a tendency to react to disruptions in reactive ways that could mean that higher education curriculum transformation becomes nothing more than a bureaucratic exercise, performed in line with neo-liberal principles such as competitiveness, performativity, and so forth. Under these circumstances, education is mostly instrumentally justified with some sort of transcendental purpose in mind - usually to equip students with the necessary skills to navigate in the world of work.

In this article, we do not concern ourselves with the discourses that necessitate curriculum transformation in higher education since much has been written about this. We affirm the need for curriculum transformation in higher education contexts, but we challenge transcendental, instrumental justifycations of curriculum transformation which are mostly the result of reactive measures taken in times of crisis. First, we employ Deleuze's concept of the plane of immanence as the starting point for thinking about how radical immanence could be understood and what it could entail. Second, we explore education on the plane of immanence. In the third part of the article we examine the implications of radical immanence for higher education curriculum transformation and consider some benefits along with possible concerns in this regard. We argue that Deleuze's notion of radical immanence should not be rejected and, instead, its pedagogical value should be exploited in combination with other philosophies of immanence, like those of Nancy (2008) and Žižek (2004). We conclude by arguing that radical immanence is crucial for our way of thinking about higher education curriculum transformation since it offers the possibility for a clear affirmation and celebration of life. It also allows for a new kind of ethical approach which is appropriate to higher education curriculum transformation insofar as it promotes an ethic that is immanent, non-normative, and one that is in-becoming, creative, and truly free.

\section{The Radical Immanence of Deleuze}

Deleuze represents one of the most radical philosophical positions of immanence. He developed the concept of the plane of immanence in various works, but particularly in What is Philosophy? (with Félix Guattari, published 
in French in 1991) and in his Two Regimes of Madness (published posthumously in 2007). His radical immanence can be described as absolute immanence, and, according to Žižek (2004), '[I]f there ever was, in the twentieth century, a philosopher of absolute immanence, it was Gilles Deleuze, with his notion of life as "the immanence of immanence, absolute immanence ... sheer power, utter beatitude"” (p. 235). But what does this mean?

Absolute immanence implies a closed world with no escape to the outside, no crossing over, and a denial even of the limits or boundaries themselves. As explained elsewhere (Verhoef 2017), a radical immanence renders the concept of transcendence redundant because transcendence virtually disappears into immanence. It implies that all transcendence is completely within this world, within our experience, within our grasp, and there is nothing more and nothing outside. Such absolute immanence positively acknowledges our interconnectedness as human beings with the material world in which we find ourselves, and our connectedness to nature and matter in being of nature and matter ourselves.

Deleuze defended such a notion of absolute immanence explicitly and passionately. He considered immanence not as a concept, but as the prephilosophical horizon against which thinking can be creative and productive a plane of immanence where 'immanence is immanent to nothing except itself' (Deleuze 2007: 385). With his passionate acceptance of immanence, Deleuze rejects any form of transcendence, connecting it with the problem of representation (Deleuze et al. 1994: 136) as 'a site of transcendental illusion' (see, also, Deleuze 2004: 334). Such representation creates the dualism of form-matter that brings with it a transcendent judgement of mind over matter. For Deleuze, it is Being that should be liberated from these chains of representation. We must thus relocate ourselves on the plane of immanence, where we will discover that 'Being necessarily only expresses Itself in all beings, because Being is all there is' (Justaert 2012: 98).

Deleuze rejects therefore all types of transcendence - epistemological and (in particular) the metaphysical. One must discover on the plane of immanence the true power and beauty in immanence, in Being, and live a life not divided into categories or hierarchies. To live on this plane of immanence is liberating - free from the illusion of transcendence and representation, hierarchy and dualism, and free to be truly creative and ethical. For Deleuze it is pure immanence that allows or calls one to be creatively and freely ethical because one is not bound to a prescribed (transcendent) morality. 
Deleuze gives two examples of how one lives on (or may experience) this plane of immanence where Being is all there is. It is important in both these examples that Deleuze speaks of 'Immanence: a life ...' (2007: 386) where the indefinite article, $a$, plays a crucial role. Being on this plane of immanence, for Deleuze, is not about the representation of life as such or in general that is important, nor the transcendent effort to live as someone, but what is beneath it, as the absolute, the immanent. Such a life, in its singularity, as impersonal, defines the plane of immanence.

We clarify this in the following two examples. First, the plane of immanence, a life, is what is experienced at the moment between life and death in the simple moment when an individual life is confronted with universal death. When someone is dying, there 'is a moment where a life is merely playing with death' (Deleuze 2007: 386). At those last few moments, before the person dies, it is not the life of the individual anymore, but an impersonal and yet singular life. This foregrounds for Deleuze (2007: 386) 'a pure event that has been liberated from the accidents of internal and external life, that is, from the subjectivity and the objectivity of what comes to pass'. This life, says Deleuze, attains a pure power and beatitude. It is 'no longer an individuation, but a singularization, a life of pure immanence, neutral, beyond good and evil' (Deleuze 2007: 387). All there is on this plane of immanence, is a life, a singular immanent life of a person who no longer has a name. Being is all there is.

The second example Deleuze gives of a life, the plane of immanence, is in relation to babies' lives. Deleuze says 'infants all resemble one another and have hardly any individuality; but they do have singularities - a smile, a gesture, a grimace - such events are not subjective traits' (2007: 387). With babies, there is no subjectivity yet, no identity, no representation or thoughts of their own. In our relation to babies we experience life - a life. It is not life in general, but life-as-singularity. It is not about a universal category called life, nor the potential of the baby's life, but rather about being alive in a singularity. It is being itself that is found here. Deleuze argues that we have some meaningful affection or sympathy towards new-born babies exactly because of this pure immanence that we experience, the 'immanent life which is pure power, and even beatitude during moments of weakness' (Deleuze 2007: 387). No further justification is needed to make it meaningful. Vlieghe and Zamojski (2019: 65) summarise this well:

Deleuze suggests that in our contact with the new-born, we experience 
a life in a 'pure' form: as life that is not yet conscious, nor attributable to any individual subject. Therefore, the life that is valuable in and of itself - immanently - is not life as we understand it from our (adult) perspective as a conscious and personal life.

Although these two examples might seem like the extreme poles of our lives (being newly born and one's moments before death), Deleuze emphasises that a life (the plane of immanence) should not be limited to only these moments. He says that a life 'is everywhere, in every moment which a living subject traverses ... an immanent life carrying along the events or singularities that are merely actualized in subjects and objects' (2007: 387). It is on this plane of immanence, on this level of preconscious and pre-subjective life, that we all live, that we all constantly move away from through representation, subjectivity, identity, etc. For Deleuze, this underlying life-as-singularity, a life, should be valued as life in its fullest sense where being is all there is. Nothing else is needed to give it value.

The radical immanence of Deleuze can thus be described as absolute immanence, as a life, as a plane of immanence, where Being is all there is. The implication is that (on this plane of immanence) '[b]eing has absorbed us as it were: our life has become a Life, an expression of Being' (Justaert 2012: 97). Such a life is impersonal, not divided into categories, and not separated from (or higher than) other beings, but a univocity of being; 'a human being's life is literally equal to a life of a rock' (Pearson 2001: 141). It is on this point, the univocity of being, that Spinoza's influence on Deleuze becomes apparent. Deleuze and Guattari (1994: 48) write about Spinoza:

Spinoza was the philosopher who knew full well that immanence was only immanent to itself and therefore that it was a plane traversed by movements of the infinite, filled with intensive ordinates. $\mathrm{He}$ is therefore the prince of philosophers. Perhaps he is the only philosopher never to have compromised with transcendence and to have hunted it down everywhere.

Deleuze follows Spinoza as the philosopher of radical immanence, of One-ness or Substance. Substance, for Spinoza, (as in the description of the plane of immanence) is the fact that there is no mediation between attributes and only a univocity of being, 'the motif on which Deleuze insists so much' (Žižek 2004: 
235). This univocity of being means there is no tension between the 'ordinary phenomenal reality and the transgressive Excess of the Real Thing' (p. 243). There is for Spinoza only a 'One-Whole Real' within our closed immanence, and Deleuze develops this idea further with his plane of immanence which implies a flat ontology in which all heterogeneous entities can be conceived of at the same level, without ontological exceptions or priorities (Verhoef 2017). Spinoza understands this univocity of being as purely positive: 'all that he admits is a purely positive network of causes and effect in which, by definition, an absence cannot play any positive role' (Žižek 2004: 236). There is no absence, gap, or crack in the Real for Spinoza. In such a universe of necessity that Spinoza portrays, there is only pure positivity of forces; there is no lifedenying negativity and only the joyful assertion of life. Deleuze follows Spinoza (and Nietzsche) ${ }^{2}$ in this affirmation of life, of this univocity of being, in this One-ness of Reality - our oneness with nature, plants, animals, and rocks, by implication. We (humans) share and participate in these positive forces of being, not as the starting point, but as being taken up into it, as a life on the plane of immanence. Deleuze compares this with modern sports like hang gliding and surfing, where there is no origin or goal (as in shot-put for example), but rather moving into an existing movement of airstreams and waves. Deleuze says that in these sports the 'key thing is how to get taken up in the motion of a big wave, a column of rising air, to 'get into something' instead of being the origin of an effort. And yet in philosophy we're coming back to eternal values, to the idea of the intellectual as custodian of eternal values' (Deleuze 1995: 121). This last remark is critique (again) on transcendent notions (of, for example, morality), as part of all his critique on transcendence. We discuss next the implication this has for morality, ethics, and specifically higher education curriculum transformation.

2 Nietzsche's amor fati is reiterated by Deleuze. Deleuze also follows Nietzsche's rejection of transcendence, so there is quite a clear line of thought between Spinoza, Nietzsche and Deleuze. Deleuze writes, for example: "We must draw up a list of these illusions and take their measure, just as Nietzsche, following Spinoza, listed the 'four great errors'. But the list is infinite. First of all, there is the illusion of transcendence, which, perhaps, comes before all the others (in its double aspect of making immanence immanent to something and of rediscovering a transcendence within immanence itself)" (Deleuze \& Guattari 1994, p. 49). 


\section{Education on the Plane of Immanence}

We have seen that Deleuze's plane of immanence - a life - implies that there are no hierarchies and no representations. There is a univocity of being where our oneness with nature is celebrated on a flat ontology with no exceptions, no priorities, but only a consistency of the Real. A first significant implication of Deleuze's radical immanence is the recognition (with Spinoza) that there are only pure positive forces in life in which we should participate on this plane of immanence, in our univocity of being. This joyful assertion and affirmation of life is not found outside of the world, but in it. Life, the here and now, is fully affirmed and meaningful; it has value in itself. It testifies to a love that is fully a worldly one - amor fati (worldy love). There is no Heideggerian onto-theology, no external grounding, and no transcendent authority (notion or Being) needed to give life meaning or value. It is, rather, the case that all life (morethan-the-human) is important and valuable.

The first implication of this for higher education curriculum transformation is that the autotelic nature of education should be appreciated and should be informed by this flattened ontology by our keeping in mind that humans have no special place in the cosmos. With the affirmation of life on this plane of immanence, it is not human lives that are affirmed, but all life and, thereby, our interconnectedness to, and inter-dependence with, all beings should be recognised. A second implication of Deleuze's plane of immanence is that there is no prescribed or transcendent morality. With radical immanence we are free from representation, free from hierarchies, and free from eternal values. Pure immanence allows or calls one, however, not to be unethical, but to be creatively and freely ethical.

To apply these implications of radical immanence to higher education curriculum transformation is quite challenging. A recent, meaningful attempt in this regard was made by Joris Vlieghe and Piotr Zamojski in their book, Towards an Ontology of Teaching (2019). In chapter five they specifically focus on 'Immanence and Transcendence in Education' when they discuss the work of Gilles Deleuze, Michel Foucault, and Giorgio Agamben. They claim that 'a transcendent account of education is dominant today' and against this, they 'call for a fully immanent view' (Vlieghe \& Piotr Zamojski 2019: 63). They highlight that radical immanence implies that there is no external ground for and/ or of education. Education is meaningful in and of itself. This notion stands in opposition to the dominant transcendent accounts of education which 
motivate, or justify, education in terms of external goals such as a just society, ethics, and religious notions.

For example, the transcendent goal of education can be to create a flourishing society; education will then be focussed on the formation of productive, accountable, and responsible citizenship. In practice we see this in versions of emancipatory pedagogy, through which education is seen as an instrument for bringing about a more just, tolerant, and equal society (e.g. Freire 2005; Giroux 2011; McLaren 2000). When education becomes the instrument for emancipation, it becomes politicised, and education is then justified, corrected, or directed from a point outside the sphere of education. Education is thereby not only instrumentalised but reduced to nothing more than the means for a transcendent goal and justification, which, in this case is to secure a well-functioning society. This transcendent goal or justification can be extremely positive and justifiable - like emancipation - but it still reduces education to a means and renders it meaningless without an outside goal.

Other examples in this regard can be seen when education is practised for economic reasons, for employability, for sociability, for qualifications, for religious purposes, and even for ethical reasons (to develop accountability, responsibility, trustworthiness, etc.). Some of these goals can easily be criticised and dismissed for various reasons, but even a fairly good goal, like an ethical account of education (see, for example, Biesta 2010; 2017), instrumentalises education because it 'is still another version of transcendent thinking: the meaning of education practices, and of teaching in special, needs to be justified by and grounded in a calling that comes from the outside' (Vlieghe \& Zamojski 2019: 74). With such external justifications, education will always be exposed and subjected to neo-liberal ideals such as effectivity, optimisation, and measurable outcomes, as with any other instrument we use. The problem with such transcendental accounts, goals, or justifications of education is that that deny the immanent meaningfulness that education already has. An immanent account of education 'is one that doesn't look for external justification: education is good in and of itself' (Vlieghe \& Zamojski 2019: 69, emphasis in original). With transcendent notions of education which makes it valuable, the immanent life itself is pushed to the background. Life (as immanent) is not affirmed, but a distrust exists. The logic is that life, with all it contains, like education, is only worthwhile if it gets justified from the outside. In other words, a transcendent account of education 'is only a coherent position to hold because it first denies the immanent meaningfulness which 
education already has' (Vlieghe \& Zamojski 2019: 70, emphasis in original). The basic assumption behind a transcendent educational approach is therefore one of distrust. This distrust is fundamentally part of the distrust and fear of radical immanence in general. Deleuze says that we fear immanence and therefore continually move back to notions of transcendence.

The problem of immanence is not abstract or merely theoretical. It is not immediately clear why immanence is so dangerous, but it is. It engulfs sages and gods. What singles out the philosopher is the part played by immanence or fire. Immanence is immanent only to itself and consequently captures everything, absorbs All-One, and leaves nothing remaining to which it could be immanent. In any case, whenever immanence is interpreted as immanent to Something, we can be sure that this Something reintroduces the transcendent (Deleuze \& Guattari 1994: 45).

With his embracing of radical immanence, Deleuze is affirming life as meaningful in itself. No gods, no sages, no Something is needed to give meaning to life. This immanence is so overwhelming, so absorbing, that it sounds dangerous. It leaves us with uncertainty of life's value itself, because we are used to justify it on transcendent grounds. ${ }^{3}$ However, Deleuze says the opposite is true: it should not instil fear or uncertainty, but joy and affirmation. This notion of radical immanence creates the possibility of a free, joyful affirmation of life. The implication for higher education curriculum transformation is that we should not be afraid to reject transcendent perspectives that education is useful only if it serves non-educational purposes. Rather, it should be seen as a meaningful endeavour in itself; education for education's sake is not dangerous, but meaningful. We should trust life. That is the underlying assumption about, and affirmation of, radical immanence in relation to higher education curriculum transformation.

To spell this out more directly we need to see education as an autotelic activity. It has its own value and goal; it is intrinsically worthwhile; it is

${ }^{3}$ The most obvious example of how we value life on transcendent grounds is found in religion. It is, for example, argued that "all higher religions require something really transcendent" (Verhoef 2013: 179), otherwise we can no longer really talk about religion. 
meaningful and important in its own right; and it is a part of life that we can and should conceive of in a purely positive way. As such, education testifies to amor fati, which brings about the possibility of transformation in the here and now. The meaning of education can thus be described as 'a free gift to the new generation and as a gift of truly free time, [and] is all about affirmation' (Vlieghe \& Zamojski 2019: 76, emphasis in original). This affirmation should be deaf to desires of a transcendent final ground. The danger lies in transcendence, not in immanence, because such a final ground might provide some comfort and safety, but in the end, it can suck away life from education.

Practically this means that one should not start with the questions of what education is all about (as if there were an external answer) and whether we are effectively reaching that goal when curriculum transformation is at hand. Rather, one should think again about the physical spaces (the here and now) and the embodiment of education. Education takes place in a 'very concrete and material arrangement, an organization of time, space, bodies and souls around a thing of study' (Vlieghe \& Zamojski 2019: 76, emphasis in original). Our starting point should therefore be concerned with 'what might happen and what we might experience against the backdrop of these arrangements' (Vlieghe \& Zamojski 2019: 76). In such a pedagogy the emphasis should be on 'experimentation, role-playing, and the questioning of power games. At the heart of this practice are an affinity with environmental concerns, the non-human world, and the subversion of commercial culture' (Cole 2016: 5). Such a pedagogy has thus an openness to new structures of thought, new forms of scientific investigations, a distancing from the canonical tradition of disciplines, and 'high degrees of social accountability' (Butler \& Braidotti 2010: 325).

This social accountability is something Vlieghe and Zamojski (2019) also highlight and discuss as an outcome of education in and of radical immanence. It is an accountability based on the univocity of being, on our interconnectedness and inter-dependence with all beings which is fully affirmed. It is an accountability that is part of the truly free and creative call on the plane of immanence, a deep or fundamental ecological response that should be part of pedagogical practices.

This accountability is not again a transcendent justification or goal of education, but is, rather, part of a responsibility that develops from our emancipation from transcendent morality. It is not an emancipatory education which will still be of conceived of in functional terms but a logic of 
responsibility principled by radical immanence. In other words, there is,

no fixed ground, there are no procedures or readymade answers that might guide us. Responses have to be invented in each situation. It is impossible, therefore, to know in advance exactly what caring for the good of the world consists of ... There are only some points of orientation that come from the subject matter itself (Vlieghe \& Zamojski 2019: 94).

Vlieghe and Zamojski (2019) furthermore explain, again without being prescriptive, that teaching in such a context requires 'connecting the present and particular situation (where a particular good is at stake) to the event of falling in love with a subject matter' (Vlieghe \& Zamojski 2019: 94). This is a notion that links back to the affirmation of life and the worldly love (of the here and now) of radical immanence.

\section{Rethinking Immanence and Higher Education Curriculum Transformation}

A pedagogy on the plane of immanence (in Deleuzian terms) where one is freed from representation, hierarchies, normative-transcendence, dualisms, and distrust has several positive implications: it allows for affirmation of life, of education as autotelic, for a flattened ontology with human beings having no special place in the cosmos, and emphasises interconnectedness and interdependence between and among all beings. While good reasons have been provided for a fully immanent pedagogy, questions about it should also be raised. For example, when does a pedagogy on the plane of immanence become too radical? Can the non-normative immanent nature of this pedagogy become dangerous, violent, and predatory? Is a pedagogy on the plane of immanence not destructive if it starts to destroy life? And why would that be wrong if that is part of our human nature? Is that not what a non-normative immanence entails?

These questions are comparable to Spinoza's naturalised ethics; 'humans should be naturalised, instead of nature being humanised' (Le Grange 2017: 8). Spinoza's ethics should be understood in terms of his notion of being as purely positive; of univocity of being; and of the One Whole Real (Substance). As discussed elsewhere (Verhoef 2017), Spinoza's strong 
assertion of the positivity and univocity of Being grounds his equation of power and right in a radical way. A right is for Spinoza to act upon things according to one's nature. In other words, 'justice means that every entity is allowed to freely deploy its inherent power-potentials, that is, the amount of justice owed to me equals my power' (Žižek 2004: 236). In a closed network of cause and effect, my power equals my right. This is an anti-legalistic notion of rights as not something which one has, but something one does according to one's nature. Spinoza uses this, for example, as his key argument for what he saw as the natural inferiority of women. He contends that '... women have not by nature equal right with men' (Spinoza 1951: 387, emphasis added).

In Spinoza's work, this equation of rights and power eventually culminates in the radical suspension of any deontological ethical dimension. He proposes an ethic of is and not of ought. Ethical laws have only been given, he argues, because of our limited connection to seeing the true causal connection in things (or in our acts), because of our lack of knowledge. There is, however, only necessity involved and not freedom and choice: ' ... in reality God acts and directs all things simply by the necessity of His nature and perfection, and ... His decrees and volitions are eternal truths, and always involve necessity' (Spinoza 1951: 65). While one may argue that the human being is thus not necessarily deprived of its 'ethico-normative distinctiveness' on this plane of immanence (Le Grange 2017: 6), it seems that the knowledge humans obtain in this process is only about 'the accurate insights into the necessities which determine us' (Žižek 2004: 237). This means that we have no freedom of choice within this closed determined One Whole Real in which we find ourselves. For Spinoza, as for Deleuze, there is no gap or crack in the Real. We can have insights only into the cause and effect of our actions in this closed system - insights that might testify to an assertion of life, but also to an indifference towards it.

With such a naturalised ethics, there seems to be no real choice (freedom), and consequently no real ethics left. All we have is the determinacy of nature (cause and effect within a closed system) and power (equated to rights). We can only say how things are, and not how they ought to be. We can even exercise our power as a right - as given by nature - as we desire. It is clear that such a non-normative or natural ethics can quickly become destructive, violent, and even life denying. A pedagogy based on such a radical immanent non-normative ethic could become unsustainable and untenable. It is not only ethics that is a problem here, but also the loss of freedom with 
complete determinism and necessity. It seems that we are doomed on this plane of immanence, within a closed whole Real, to have no real free choices. These two issues, the possibility of an ethics, and the possibility of freedom, are, however, both addressed by Deleuze in his philosophy, and it is crucial that we should examine this further.

As mentioned above, Deleuze (2007), with his plane of immanence, insists on the univocity of being. This plane of immanence implies a flat ontology, in line with Spinoza, in which all heterogeneous entities can be conceived of at the same level, without ontological exceptions or priorities. This implies that we (as subjects) and the objects are both constituted by each other. Deleuze emphasises that both are becoming in this univocity of being. What 'seems to separate us from the way reality really is out there is already the innermost constituent of reality itself' (Žižek 2004: 244). That we cannot ever fully know reality is not a sign of the limitation of our knowledge, but 'the sign that reality itself is 'incomplete', open, an actualization of the underlying virtual process of Becoming' (Žižek 2004: 244). There is thus an openness, a dynamic becoming on this plane of immanence within this univocity of Being. This differentiates Deleuze from Spinoza in a crucial way in terms of ethics and freedom.

Ansell-Pearson (2017) and Le Grange (2017) explain clearly that Deleuze's Spinozism does not flatten ontology without a concern with issues of normativity (as some new materialists will read Spinoza). Deleuze's interpretation of Spinoza allows, for example, an ethical task of human emancipation in that Spinoza first allows for a better understanding of 1) how nature works (how we are implicated in it), but also 2) how we (as humans) are moved, in and by nature's forces, from passivity to a better active condition. Deleuze emphasises that we are in becoming. We have an active position within reality (this One Whole Real of Spinoza) where 1) an understanding of nature involves a sensibility of our interconnectedness, and 2) the appreciation that 'the human animal holds no special ontological place, but concerns a deep awareness of the need to take action in respecting and caring for the morethan-human-world' (Le Grange 2017: 6, emphasis in original). This is possible because of the human animal's individual and separate conatus (a Spinozian term that refers to the essence of modes or that which makes the individual thing persist) which allows it to have a greater number of affects. Affects are not about feelings or affections, but the 'potential-power of the body' (Deleuze et al. 1994: 154). Affects are 'beings whose validity lies in themselves and 
exceeds any lived' (Deleuze et al. 1994: 164, emphasis in original). ${ }^{4}$ For Deleuze, one should define an animal or human being 'by the number of affects it is capable of' (Deleuze 1988: 124). Although there is no ontological privilege for human beings on the plane of immanence, there is a difference between humans and animals (and rocks) in terms of their affects. We should discover this as part of a life of experimenting because we do not know what affects we are capable of. Ansell-Pearson writes,

In terms of our becoming-ethical we can say that we do not know what a body can do: it is a mode of practical living and experimenting, as well as, of course, a furthering the active life, the life of affirmativity, for example, cultivating the active affects of generosity and joyfulness, as opposed to the passive and sad affects of hatred, fear and cruelty (2017: 6).

For Deleuze and Guattari (1994) our becoming is happening at the same time as everything else's becoming. There is a continuous flux of pure becoming, on this plane of immanence (the flat ontology), one that is dynamic and open ended. It is a process of infinite becoming wherein we (as humans) may become aware of (or develop a sensibility to) our affects, our 'energetic relationships' (Deleuze \& Guattari 1994: 132) and the affects and forces of which we are part. A Spinozian ethics calls one to cultivate active affects 'through being open to be affected by non-human modes, including nonsentient ones' (Le Grange 2017: 6). It means that we as humans do not inhabit earth, but that earth (and all its forces) inhabits us; we (as subjects) are getting absorbed. There is a rendering of the subject of imperceptible that should take place on this plane of immanence. Such active affects should (and here we find the normative of Deleuze's Spinozism) be an active becoming on this flat ontology: in other words, we should use our power (affects) to promote the

${ }^{4}$ Affect is discussed by Deleuze and Guattari in chapter seven of What is Philosophy? (1994). Important, in terms of our argument, is that they describe affect as "[t]his something can be specified only as sensation. It is a zone of indetermination, of indiscernibility, as if things, beasts, and persons ... endlessly reach that point that immediately precedes their natural differentiation. This is what is called an affect" (Deleuze \& Guattari 1994, p. 173). 
interest of all life thus enhancing all life. This asks for understanding and experimentation on how to construct viable notions of good and evil in order to enhance life. Le Grange formulates the implication for this for education clearly.

[A]lthough Deleuze's Spinozism does not privilege the human on an ontological level, it does not deny its ethico-normative distinctiveness. It is this ethico-normative distinctiveness of the human animal that is at the heart of an education aimed at cultivating (post)human sensibilities; an education that involves expanding the powers that enhance all life. Such an education involves a life-long affair of experimentation. But it does not simply mean exposing students to a range of different experiences, but in breaking old associations and forging new ones through a process of reasoning (2017: 8).

Deleuze's (1994) emphasis on the notion of becoming on the plane of immanence thus allows for a reading of Spinoza's ethics where there is an immanent normative at play. This is not a transcendent, deontological, eternal truth (etc.) that is normative, but an open one, and one that is constantly discovered and experienced on the plane of immanence where human beings exercise their bodily power and are affected by all forces of nature. It is a becoming where life itself is crucial. It is a non-normative ethic in that it denies a transcendent norm, but normative in the sense that we are interdependent and interconnected with all beings in a fundamental way. It implies an awareness of the univocity of being on the plane of immanence, but one where human beings retain an ethico-normative distinctiveness.

The question remains, however, whether there is not a loss of freedom, and of complete seizure of freedom by determinism and the necessity on this plane of immanence, within Spinoza's closed whole Real. If there is no gap or crack within this radical immanence, we seem to be trapped within the determinacy of nature (cause and effect). Deleuze emphasises that the plane of immanence is one of consistency (in agreement with Spinoza), but he adds that everything is becoming on this flat ontological plane. This creates an 'openness which aims to avoid the deterministic, all-totalising, Spinozan One-Whole Real' (Verhoef 2017: 10). Although it aims to avoid this, there is a question of whether it succeeds. In other words, if the ontological consistency of Deleuze's plane of immanence is taken seriously, it limits the Real, because for Deleuze 
there cannot be any exceptions of priorities within this flat ontology. The human being has, for example, no priority or ontological privilege on this plane of immanence. There is no gap, no crack in Deleuze's radical immanence. There is, however, movement, along with becoming, dynamic forces, and affects, but one may argue (as Žižek 2004) does, that these are still confined to the limited space (the Real) of the plane of immanence.

It is on this point that it is crucial that Deleuze's radical immanence should be complemented by the work of Slavoj Žižek (2004) and Jean-Luc Nancy (2008). This will not entail a move away from immanence. It will not deny the importance of an immanent view of higher education curriculum transformation, as argued above in agreement with Vlieghe and Zamojski (2019), but a more nuanced understanding of immanence that will allow more human freedom, and a tenable appropriation to education.

Žižek (2004) speaks of a crack or a gap in immanence, which for him allows some inconsistencies on the plane of immanence, without moving to a transcendent position. As explained elsewhere, Žižek follows Hegel, who

broadens the Real (and by implication freedom) with his acceptance of the irreducible rupture of/ in immanence which is in phenomena themselves and which amounts to an inconsistency within phenomena. By accepting this inconsistency within phenomena and the inconsistency within immanence itself, a gap or crack is allowed (albeit immanent) which disturbs the 'plane of consistency', the 'flat ontology'. In this way the all totalising Real is 'ruptured', becomes more inclusive for the transcendental dimension, and allows for the 'transcendent Beyond' (as immanence) to 'shine through' (Verhoef 2017: 10).

Žižek (2004) thus allows for a gap in immanence, for a disruption of the flat ontology, so that everything is not simply reduced to causality. He allows something imperceptible, for a light to shine through, for the gap that will allow human freedom.

In the same vein, Jean-Luc Nancy (2008) maintains that we have only this world. Nancy is also a radical immanent thinker and rejects transcendence completely. He does, however, move away from the notion of a closed-off immanence, or the radical immanence of Deleuze, with his concept of transimmanence. With transimmanence (trans + immanence) there seems to be 
a definite choice for immanence, but a trans, a type of crossing over takes place from this immanence. This, according to Nancy, happens in our existence per se, 'in our infinite relationships where sense cuts across (trans-) between others, not as a crossing that goes outside, but passes toward an outer within world' (Verhoef 2016: 12). Nancy remarks that '[w] hat 'is not of this world' is not elsewhere: it is the opening in the world, the separation, the parting and the raising' (2008: 48). The opening in the world is the sense (meaning) that continuously circulates, which we continually create. There is thus, for Nancy, an opening (a gap) within immanence, but as with Žižek, it remains an opening within immanence.

There is a minimal difference here that separates Deleuze's immanence (as a flat ontology) from Žižek's gap in immanence and Nancy's transimmanence (as both still being immanent). The importance of this minimal difference (gap, crack, or trans in immanence) is that it avoids a complete full totalising Real (plane of consistency) - the deterministic Spinozan One-Whole Real - to allow more human freedom, and eventually a tenable appropriation of radical immanence to higher education curriculum transformation. It is on this point that we move beyond the work of Le Grange (2016 2017), and Vlieghe and Zamojski (2019) (among others) and where we aim to evoke further conversation on the importance of this gap or crack in immanence.

\section{Conclusion}

Deleuze's radical immanence is of crucial importance for our way of thinking about life (as such) and therefore also of higher education curriculum transformation. His plane of immanence offers the possibility for a clear affirmation and celebration of life. This has significant (and exciting) implications for pedagogy, namely that it allows for a move away from restrictions, prescriptions, or justification of education from any transcendent point of view. Education is understood as autotelic and it should celebrate itself - and life - as such. It furthermore allows for a flattened ontology where human beings have no special place, and where interconnectedness and interdependence between all beings are emphasised.

The question could be raised whether such a pedagogy in and of radical immanent might not be too radical? Will it not be a complete unethical pedagogy, even a destructive one? The answer to this question is that Deleuze's 
radical immanence does allow for a new kind of ethical approach which is appropriate to higher education curriculum transformation - an ethic that is immanent, non-normative, and one that is in becoming, creative, and truly free. It is an ethic of in becoming, of exercising one's power with and within other beings - one where human beings retain an ethico-normative distinctiveness on a flat ontology. This flat ontology, or plane of immanence, should, however, not be understood as a closed One Whole Real (where determinism rules), but one where there is a possible gap, crack or trans within the immanence.

\section{References}

Ansell-Pearson, K. 2016. Deleuze and New Materialism: Naturalism, Norms and Ethics. In S. Ellenzweig \& and J. H. Zammito (eds.): The New Politics of Materialism: History, Philosophy, Science. New York: Routledge.

Biesta, G.J.J. 2010. Good Education in an Age of Measurement. Ethics, Politics, Democracy. Boulder/London: Paradigm Publisher.

Biesta, G.J.J. 2017. The Rediscovery of Teaching. New York/London: Routledge. https://doi.org/10.4324/9781315617497

Butler, J. \& R. Braidotti. 2010. Out of Bounds: Philosophy in an Age of Transition. In Schrift, A.D. (ed.): The History of Continental Philosophy after Poststructuralism: Transitions and Transformations (Vol. 7). Chicago: University of Chicago Press.

Cole, D.R. 2016. Unmaking the Work of Pedagogy through Deleuze and Guattari. In Peters, M.A. (ed.) Encyclopedia of Educational Philosophy and Theory. Singapore, Springer.

https://doi.org/10.1007/978-981-287-532-7_67-1

Deleuze, G. 1988. Spinoza: Practical Philosophy. R. Hurley (trans.). San Francisco: City Light Books.

Deleuze, G. 1995. Negotiations, 1972-1990. M. Joughin (trans.). New York: Columbia University Press.

Deleuze, G. 2004. Difference and Repetition. P. Patton (trans.). New York, Continuum.

Deleuze, G. 2007. Two Regimes of Madness: Texts and Interviews 1975-1995. New York: Semiotext(e).

Deleuze, G. \& F. Guattari. 1994. What is Philosophy? H. Tomlinson \& G. Burchell (trans.). New York: Columbia University.

Du Preez, P., S. Simmonds \& A. Verhoef. 2016. Rethinking and Researching 
Transformation in Higher Education: A Meta-study of South African Trends. Transformation in Higher Education 1, 1: 1-7.

https://doi.org/10.4102/the.v1i1.2

Du Preez, P. 2018. On Decolonisation and Internationalisation of University

Curricula: What Can we Learn from Rosi Braidotti? Journal of Education

74: 19-31. https://doi.org/10.17159/2520-9868/i74a02

Du Preez, P. \& L. Le Grange 2020. The COVID-19 Pandemic, Online

Teaching/Learning, the Digital Divide, and Epistemological Access. In

Ramrathan, L., J. Smit, N. Hlongwe, \& N. Mkhize (eds.): Humanities

Curriculum within the Context of COVID-19. Durban: Alternation.

Freire, P. 2005. Pedagogy of the Oppressed. New York/London: Continuum.

Giroux, H.A. 2011. On Critical Pedagogy. New York/London: Continuum. Halberstam, J. 2019. Strategy of Wildness. Critique \& Praxis 13, 13.

Available at: http://blogs.law.columbia.edu/praxis1313/jack-halberstamstrategy-of-wildness/?cn-reloaded=1

(Accessed 20 November 2019).

Howard, P.G. 2018. Twenty-first Century Learning as a Radical Re-Thinking of Education in the Service of Life. Education Sciences 8, 189: 1-13.

https://doi.org/10.3390/educsci8040189

Justaert, K. 2012. Gilles Deleuze and the Transcendence of Immanence. In

Stoker, W. \& W.L. van der Merwe (eds.): Looking Beyond? Shifting Views of Transcendence in Philosophy, Theology, Art, and Politics. Amsterdam: Rodopi.

Le Grange, L. 2016. Decolonising the University Curriculum. South African Journal of Higher Education 30, 2: 1-12.

https://doi.org/10.20853/30-2-709

Le Grange, L. 2017. Spinoza, Deep Ecology and Education Informed by a (Post)human Sensibility. Education Philosophy and Theory 50, 9: :1-10. https://doi.org/10.1080/00131857.2017.1384723

Le Grange, L., P. Du Preez, L. Ramrathan \& S. Blignaut. 2020. Decolonising the university curriculum or decolonial-washing? A multiple case study. Journal of Education 80, forthcoming.

https://doi.org/10.4324/9781351061629-14

Lourie, M. 2020. Recontextualising Twenty-First Century Learning in New Zealand Education Policy: The Reframing of Knowledge, Skills, and Competencies. New Zealand Journal of Educational Studies 55, 113-128. https://doi.org/10.1007/s40841-020-00158-0 
McLaren, P. 2000. Che Guevara, Paolo Freire, and the Pedagogy of Revolution. Lanham/Oxford: Rowman \& Littlefield.

Nancy, J-L. 2008. Noli Me Tangere: On the Raising of the Body. Cliff, S, P-A. Brault \& M. Naas (trans.). New York: Fordham University Press.

Pearson, K.A. 2001. Pure Reserve: Deleuze, Philosophy and Immanence. In Bryden, M. (ed.): Gilles Deleuze and Religion. London: Routledge.

Spinoza, B. 1951. A Theologico-Political Treatise and a Political Treatise.

New York: Dover Publications.

Verhoef, A.H. 2013. Embodied Religion's Radicalisation of Immanence and the Consequent Question of Transcendence. Acta Academica 45, 4: 173194.

Verhoef, A.H. 2016. Transimmanence and the Im/possible Relationship between Eschatology and Transcendence. Religions 7, 35: 1-15. https://doi.org/10.3390/rel7110135

Verhoef, A.H. 2017. Encountering Transcendence: Žižek, Liberation Theology and African Thought in Dialogue. Religions 8, 271: 1-14.

https://doi.org/10.3390/rel8120271

Vlieghe, J. \& Zamojski, P. 2019. Towards an Ontology of Teaching. Thingcentred Pedagogy, Affirmation, and Love for the World. Cham: Springer. https://doi.org/10.1007/978-3-030-16003-6

Žižek, S. 2004. The Descent of Transcendence into Immanence, or Deleuze as a Hegelian. In Schwartz, R. (ed.): Transcendence, Philosophy, Literature, and Theology. Approach the Beyond. New York, Routledge.

Anné Verhoef Professor School of Philosophy North-West University

Potchefstroom anne.verhoef@nwu.ac.za

Petro du Preez Professor School of Professional Studies in Education

North-West University

Potchefstroom petro.dupreez@nwu.ac.za 